\title{
Impact of El Niño 2015-2016 on the coral reefs of the Pacific of Costa Rica: the potential role of marine protection
}

\author{
Juan José Alvarado ${ }^{1,2,3 *}$, Celeste Sánchez-Noguera ${ }^{1}$, Gustavo Arias-Godínez¹, Tatiana Araya ${ }^{1}$, \\ Cindy Fernández-García ${ }^{1,2,4}$ \& Ana Gloria Guzmán ${ }^{5}$ \\ 1. Centro de Investigación en Ciencias del Mar y Limnología (CIMAR), Universidad de Costa Rica (UCR), San Pedro, \\ 11501-2060 San José, Costa Rica; juanalva76@yahoo.com, celeste08@gmail.com, gustavoarg7@gmail.com, \\ tatianaraya259@yahoo.com, cindyfdez28@gmail.com \\ 2. Escuela de Biología, Universidad de Costa Rica. \\ 3. Museo de Zoología, Universidad de Costa Rica. \\ 4. Herbario de la Universidad de Costa Rica (USJ). \\ 5. Conservación Internacional; aguzman@conservation.org \\ * Correspondence
}

Received 07-I-2019. Corrected 25-IV-2019. Accepted 14-VI-2019.

\begin{abstract}
Introduction: El Niño 2015-2016 was considered one of the most severe worldwide, causing the third global event of coral bleaching. Previous high-intensity El Niño events (1982-83 and 1997-98) caused high coral mortalities and deterioration of coral reef structures along the Eastern Tropical Pacific, affecting both ecosystem and associated economical activities. Objective: The aim of this study was to determine the impact of the most recent El Niño event on coral reefs from Cocos Island and the Pacific coast of southern Costa Rica. Methods: Coral reefs were surveyed before (2013-2014) and after (2016) the disturbance, using underwater visual censuses within belt transects, to quantify the bottom coverage at different depths. Results: In general, average live coral cover decreased 50\% after the 2015-2016 El Niño event, with Golfo Dulce being the most affected area with $75 \%$ of live coral cover decline. However, in certain localities such as Isla del Coco and Isla del Caño, the effects of El Niño were apparently minimal, since no substantial loss of live coral cover was detected. Differences in the level of deterioration found between coral reefs could be related to several factors, including the age of the protected area, the distance to centers of human population, and the effectiveness in the application of management strategies. Conclusions: The synergistic impact of the 2015-16 El Niño event and other stressors (e.g. illegal fishing and unregulated coastal human development) increased the levels of disturbance on coral reefs, threatening their structure and functioning. It is necessary to strengthen conservation strategies in order to improve the resilience of coral reefs to the impact of natural and anthropogenic disturbances. Concrete actions such as coral reef restoration, marine environmental education, and marine spatial planning must become important tools to maintain the good health of coral reefs and ensure the sustainability of the goods and services provided by these ecosystems.
\end{abstract}

Keywords: coral bleaching; El Niño; crustose coralline algae; conservation strategies; marine protected areas; resilience; Cocos Island.

Alvarado, J. J., Sánchez-Noguera, Arias-Godínez, C. G., Araya, T., Fernández-García, C., \& Guzmán, A. G. (2020). Impact of El Niño 2015-2016 on the coral reefs of the Pacific of Costa Rica: the potential role of marine protection. Revista de Biología Tropical, 68(Suppl. 1), S271-S282.

In the last 40 years, coral reefs around the world have suffered great losses due to climatic extremes associated with the El Niño-Southern Oscillation. The 1982-1983 El Niño event caused coral mortalities of up to $90 \%$ in various locations in the Eastern Tropical Pacific (Glynn, Cortés, Guzmán, \& Richmond, 1988; Glynn, Mones, Podestá, Colbert, \& Colgan, 
2017). The 1997-1998 event is recognized globally as the first massive coral bleaching event, with serious impacts on reef health. Subsequently, two other El Niño events have had global scale impacts (2010 and 2015). The latter was called El Niño-Godzilla (Schiermeier, 2015) because it developed into one of the largest recorded events (Claar, Szostek, McDevitt-Irwin, Schanze, \& Baum, 2018), producing heat waves with devastating effects for marine ecosystems (Frölicher \& Laufkötte, 2018). A global analysis of the impact of El Niño 2015-2016, which included more than 100 reefs, determined that $75 \%$ of these ecosystems suffered moderate to severe bleaching (Hughes et al., 2018, 2019).

In Costa Rica, El Niño 1982-1983 impacted several locations in the Pacific and the Caribbean, causing heavy coral bleaching and mortality (Cortés, Murillo, Guzmán, \& Acuña, 1984). The best-documented effects were at Isla del Caño, where up to $50 \%$ of live coral cover (LCC) was lost between 1980 and 1984 (Guzmán, Cortés, Richmond, \& Glynn, 1987). Isla del Coco also experienced a drastic reduction in LCC, reaching average values between 2 and 3\% (Guzman \& Cortés, 1992).

During the El Niño of 1991-1992, reefs along the central Pacific coast of Costa Rica experienced $57 \%$ bleaching and $9 \%$ coral mortality (Jiménez \& Cortés, 2001). That same region was severely impacted during the 1997 1998 event, with a nearly $50 \%$ reduction in LCC at some sites (Jiménez \& Cortés, 2003). In comparison to the 1991-1992 event, however, the 1997-1998 event resulted in higher percentages of coral bleaching $(62 \%)$, but lower mortality (6\%) (Jimenez et al., 2001). In the northern Pacific coast of Costa Rica, bleaching only affected $32 \%$ of the colonies, however, small populations of the coral Leptoseris papyracea experienced mortalities of up to $90 \%$. In the South Pacific, specifically in Golfo Dulce, the percentage of bleaching was higher $(70 \%)$ than in the northern coast of the country and mortality reached up to $12 \%$ of the colonies (Jiménez, Cortés, León, \& Ruiz, 2001). In Isla del Caño, the mortality associated with the 1997-1998 event was 5\%, which suggests a greater tolerance of these corals in comparison with other Pacific localities (Guzmán \& Cortés, 2001). In contrast, the corals of Isla del Coco underwent intense bleaching, but with lower coral mortality compared to previous El Niño events; between 1987 and 2002, a recovery of LCC was observed, which increased from 3\% to $23 \%$ (Guzmán \& Cortés, 2007).

In the last 40 years, marine conservation strategies in Costa Rica have focused on the creation of Marine Protected Areas (MPAs) that can safeguard vulnerable ecosystems (Alvarado, Cortés, Esquivel, \& Salas, 2012). Most of these MPAs include coral reefs as conservation elements (Alvarado, Herrera, Corrales, Asch, \& Paaby, 2011; Alvarado et al., 2017), and the reduction of certain anthropogenic pressures (fishing, tourism, sewage) in these MPAs is thought to result in greater resilience and reproductive success for reefs (Hughes, Graham, Jackson, Mumby, \& Steneck, 2010; Mumby \& Steneck, 2011; Richmond, Tisthammer, \& Spies, 2018). Therefore, this research seeks first to determine the impact of the most recent El Niño event (2015-2016) on the coral reefs of the Pacific coast of southern Costa Rica and Isla del Coco, as well as to quantify if the established conservation actions (MPAs) have been key in the resilience of these ecosystems.

\section{MATERIALS AND METHODS}

Between 2013 and 2017, a series of coral reefs health assessments in the Pacific of Costa Rica were conducted (Alvarado, Beita, Mena, Fernández-García, \& Guzmán, 2015; Alvarado et al., 2016, 2018). These assessments focused solely on establishing the health status of these ecosystems, and here provides the baseline of their condition prior to the 2015-2016 global warming event. Repeated assessments at the same sampling sites were used to quantify the impact of the 2015-2016 El Niño event on benthic composition and percent cover. In Isla del Coco $\left(5^{\circ} 33^{\prime} \mathrm{N}-87^{\circ} 02^{\prime} \mathrm{W}\right)$, two preevent evaluations were carried out (July 2013 and February-March 2014) and one after the 
event (December 2016). In the southern coastal sites $\left(9^{\circ} 13^{\prime} \mathrm{N}-83^{\circ} 50^{\prime} \mathrm{W}\right.$ and $\left.8^{\circ} 38^{\prime}-83^{\circ} 17^{\prime} \mathrm{W}\right)$ the pre-El Niño assessments were carried out in February 2013 and January 2014 and one after the event in January 2017.

To describe the behavior of the sea surface temperature (SST) and the degree heating weeks (DHW), the monthly averages data were obtained, from both locations, since January 2012 to December 2017 of the Pacific Islands Ocean Observing System platform (http: //pacioos.org).

The benthic coverage of coral reef communities was estimated using underwater visual censuses via scuba. On each reef, 10 to 15 $10-\mathrm{m}$ long transects were arranged parallel to the coast and separated from each other by $3 \mathrm{~m}$ (Weinberg, 1981). A $1 \mathrm{~m}^{2}$ grid divided into 0.01 $\mathrm{m}^{2}$ cells was placed along each transect to cover the entire 10-m length. Each diver counted the number of cells occupied by different substrate categories: live coral, macroalgae, algal carpet or "turf", and crustose coralline algae (CCA). In Isla del Coco, work was carried out at three depths (shallow 4-8 m, intermediate 9-12 m, and deep 13-16 m), while along the southern coast, two depths were surveyed (shallow 2-8 $\mathrm{m}$ and deep 8-16 $\mathrm{m}$ ). The differences in the bathymetric distribution of the surveys are due to the fact that in Isla del Coco the reefs are more complex and grow deeper than the coastal reefs of the South Pacific of Costa Rica.

To determine if conservation strategies influenced the response (changes in LCC) of coral reefs to the impact of El Niño 201516 , each site was classified into one of three management categories: 1) Marine Protected Area (MPA) (managed by the Ministry of Environment and Energy), 2) Marine Responsible Fishing Area (MRFA) (managed by the Costa Rican Institute of Fisheries and Aquaculture), and 3 ) unprotected site (NoMPA) (Table 1).

To compare the pre and post-El Niño (20152016) condition of the coral reefs of the Costa Rican Pacific, a Bray-Curtis similarity matrix was constructed using the average percentage cover of each substrate category, by location and year, after standardizing and transforming $\left(\log _{10}(\mathrm{x}+1)\right)$ the values. The management category of each locality (MPA, MRFA, NoMPA) and the years sampled $(2013,2014,2016)$ were considered as factors. From the similarity values, a non-metric multi-dimensional scaling analysis (nMDS) and an analysis of similarities (ANOSIM) were performed. Likewise, in order to determine which substrates contributed most to the similarity between management categories and year, a similarity percentage-species contribution test (SIMPER) was performed. All analyses were performed with the software PRIMER 7 (Clarke \& Gorley, 2015).

\section{RESULTS}

For both locations, an increase in the SST is observed for the second semester 2015 and the first semester 2016, with average temperatures above $29.5^{\circ} \mathrm{C}$. However, there is a slight difference between Isla del Coco and Golfo Dulce, in terms of the duration of these hot periods. It was observed that DHW, which may

TABLE 1

Reef locations in the Pacific of Costa Rica where the bottom was evaluated between 2013 and 2016. MPA: Marine Protected Area; MRFA: Marine Responsible Fishing Area; NoMPA: unprotected site

\begin{tabular}{|c|c|c|c|c|}
\hline Locality & Coordinates & $\begin{array}{c}\text { Management } \\
\text { category }\end{array}$ & $\begin{array}{c}\text { Year of } \\
\text { establishment }\end{array}$ & $\begin{array}{l}\text { Shortest distance to } \\
\text { human population center }\end{array}$ \\
\hline Isla del Coco & $5^{\circ} 32^{\prime} 45.40^{\prime \prime} \mathrm{N} 87^{\circ} 3$ '44.30” W & MPA & 1978 & $550 \mathrm{~km}$ \\
\hline Dominicalito & $9^{\circ} 13^{\prime} 31.80^{\prime \prime} \mathrm{N} 83^{\circ} 50^{\prime} 47.30^{\prime \prime} \mathrm{W}$ & NoMPA & - & $<1 \mathrm{~km}$ \\
\hline Marino Ballena & $9^{\circ} 6 ’ 23.80^{\prime \prime} \mathrm{N} 83^{\circ} 43^{\prime} 34.20^{\prime \prime} \mathrm{W}$ & MPA & 1992 & $<1 \mathrm{~km}$ \\
\hline Isla del Caño & $8^{\circ} 42^{\prime} 45.70^{\prime \prime} \mathrm{N} \quad 83^{\circ} 53^{\prime} 23.20^{\prime \prime} \mathrm{W}$ & MPA & 1978 & $24 \mathrm{~km}$ \\
\hline Península de Osa & $8^{\circ} 40^{\prime} 15.58^{\prime \prime} \mathrm{N} \quad 83^{\circ} 43^{\prime} 5.44^{\prime \prime} \mathrm{W}$ & NoMPA & - & $10 \mathrm{~km}$ \\
\hline Golfo Dulce & $8^{\circ} 39^{\prime} 25.40^{\prime \prime} \mathrm{N} \quad 83^{\circ} 16^{\prime} 27.80^{\prime \prime} \mathrm{W}$ & MRFA & 2010 & $<1 \mathrm{~km}$ \\
\hline
\end{tabular}


be evidence of coral bleaching $\left(>4^{\circ} \mathrm{C}\right.$-weeks), were more persistent for Golfo Dulce than for Isla del Coco (Fig. 1).

Over the study period, LCC was higher in either MPA or MRFA sites (18.17 $\pm 3.86 \%$ and $24.72 \pm 8.61 \%$, respectively), compared to NoMPA sites (7.39 $\pm 3.23 \%)$ (Fig. 2A). Within MPAs, CCA coverage $(12.25 \pm 2.70 \%)$ was also higher than in NoMPAs $(6.00 \pm 1.40 \%)$. In NoMPAs, the predominant substrates were macroalgae $(2.56 \pm 0.87 \%)$ and turf $(67.51 \pm 4.89 \%)$ (Fig. 2A).

LCC averaged across all sites decreased by $25-50 \%$ between pre-El Nino (2013: $14.90 \pm 3.89 \%$ and $2014: 20.35 \pm 5.42 \%)$ and post El Niño (11.75 $\pm 5.73 \%)$ surveys. The coverages of CCA, macroalgae, and turf remained stable and even showed a slight increase post El Niño (Fig. 2B).

El Niño impacts differed across the evaluated locations. For example, the benthic compositions of coral reefs of Isla del Coco and Isla del Caño were not substantially affected during the study period (Fig. 3). Reefs of Isla del Coco experienced a post-El Niño increase in LCC from an average of $28.83 \pm 6.44 \%$ in $2013 / 2014$ to $38.16 \%$ in 2016 . LCC at Isla del Caño decreased slightly from $19.71 \%$ prior El Niño to $15.79 \%$ post El Niño. In contrast, moderate to drastic losses in LCC were observed at Marino Ballena $(8.26 \%$ to $2.80 \%)$ and Dominical ( $4.3 \%$ to $0.05 \%)$. In both locations, dissimilarities in benthic composition were also observed pre- and post El Niño (ANOSIM: $\mathrm{R}=0.22$,
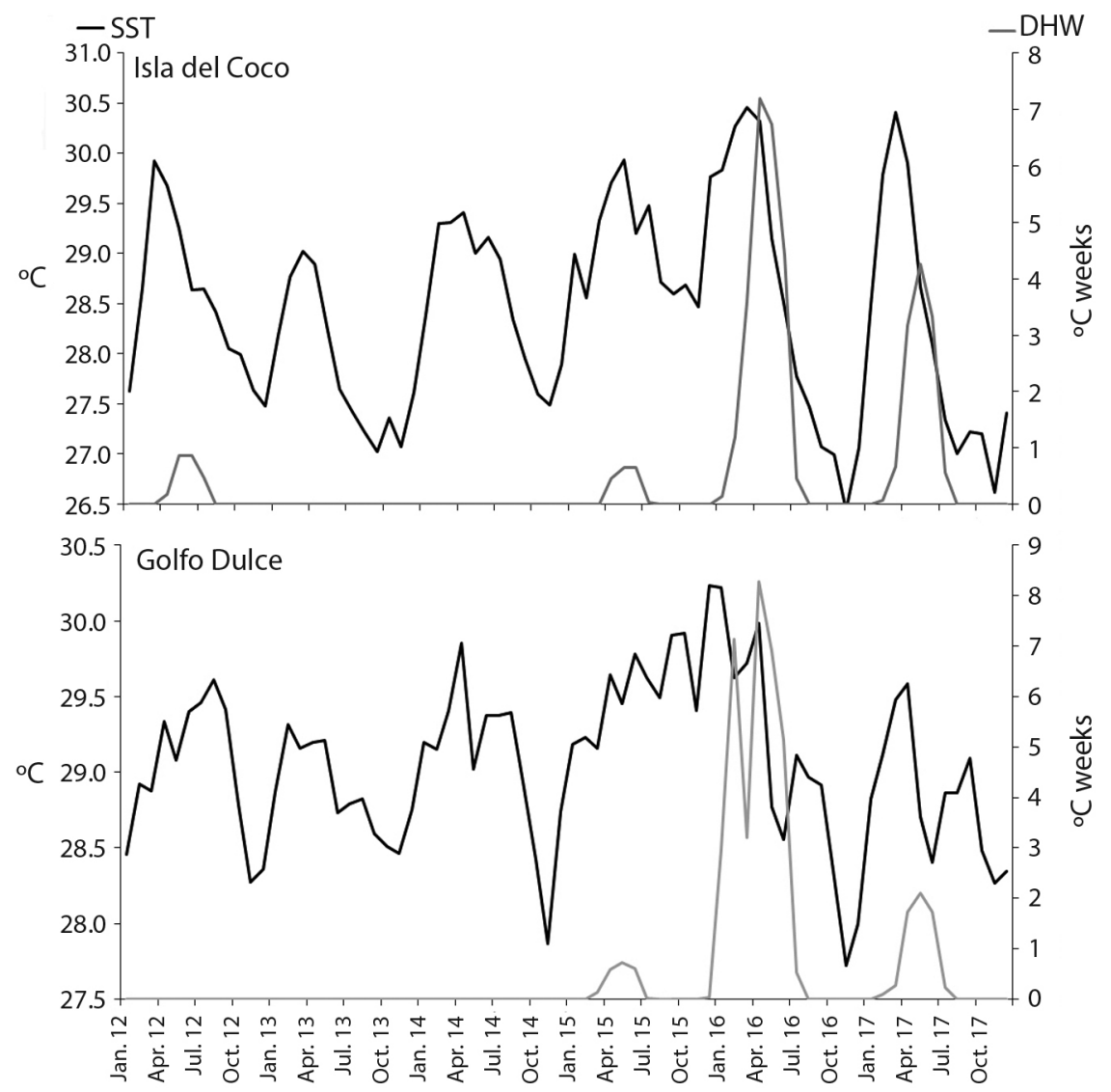

Fig. 1. Surface sea temperature (SST) $\left({ }^{\circ} \mathrm{C}\right)$ (black line) and degree heating weeks (DHW) $\left({ }^{\circ} \mathrm{C}\right.$ weeks) (gray line) in Isla del Coco and Golfo Dulce form January 2012 until December 2017. 

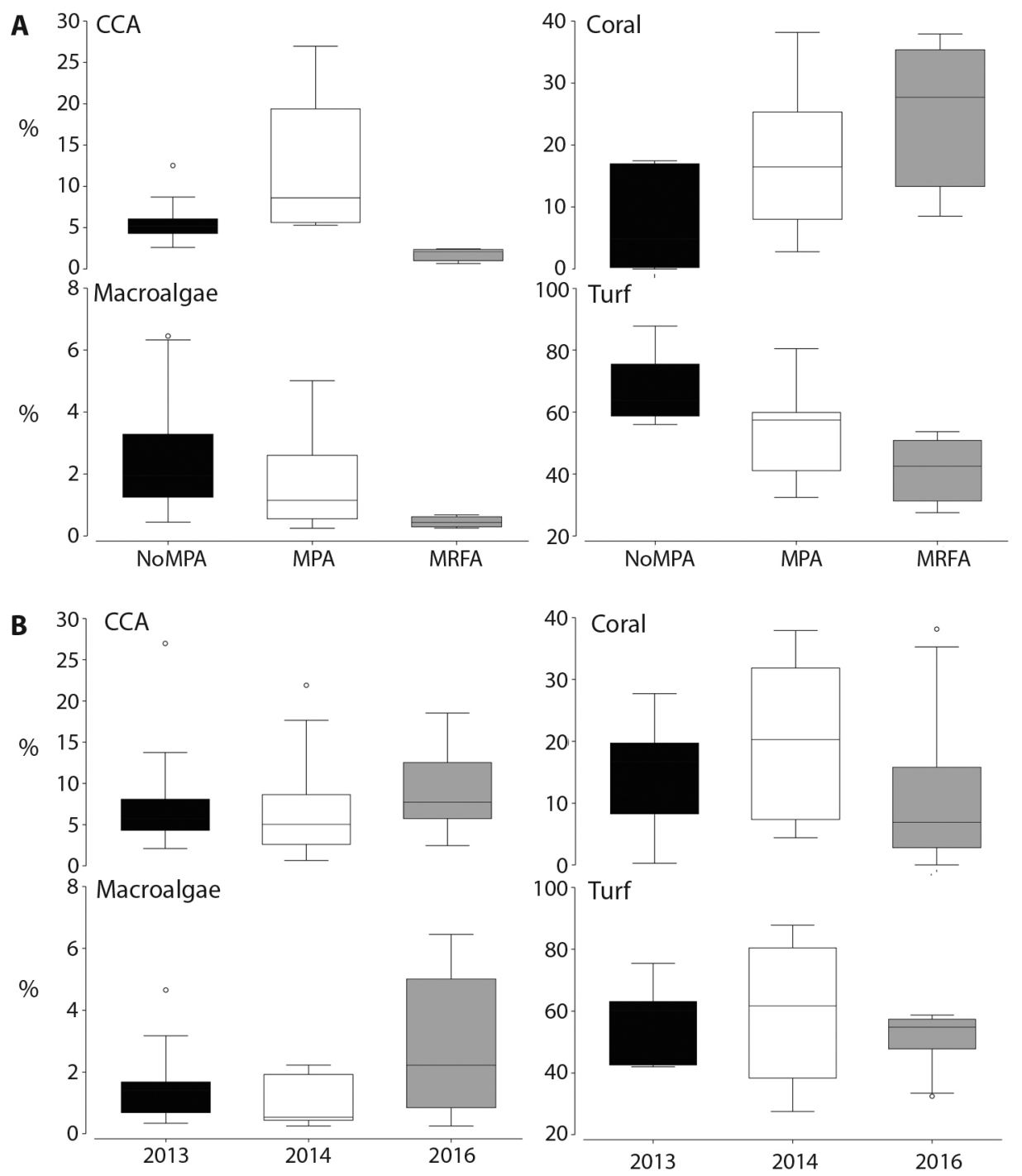

Fig. 2. Average percentage coverage (\%) of crustose coralline algae (CCA), live coral, macroalgae and turf according to A) Management category (MPA: Marine Protected Area, MRFA: Marine Responsible Fishing Area, NoMPA: Unprotected site) and B) year of sampling; in the coral reefs of the Pacific of Costa Rica.

$\mathrm{p}<0.05$ ) (Fig. 3). The most drastic reductions in LCC occurred on reefs of the Peninsula de Osa (from $17.00 \%$ to $5.23 \%$ ), and of Golfo Dulce (from $37.90 \%$ to $8.54 \%$ ).

These differences largely reflect the conservation strategy implemented at each locality. At the protected sites (MPA and MRFA) LCC and CCA were higher than at the unprotected sites (Table 2). Differences between sites within the same conservation category, however, reflected the contribution of CCA, as observed at Isla del Coco or Isla del Caño (Fig. 3). LCC and CCA also accounted for the largest differences in pre and post El Niño compositions, where some sites maintained similar LCC and CCA coverage over time, while others changed. 
Stress level: 0.06

ANOSIM: R: $0.22, \mathrm{p}<0.05$

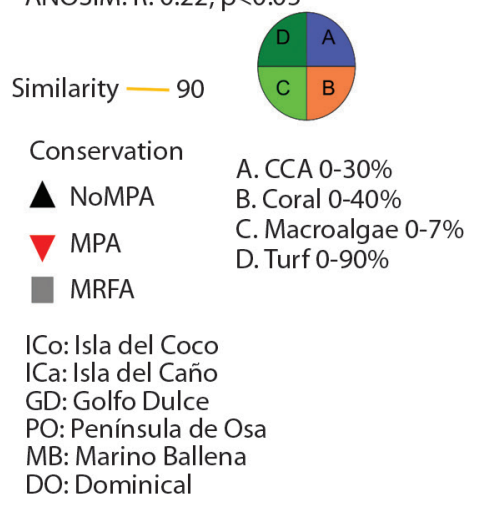

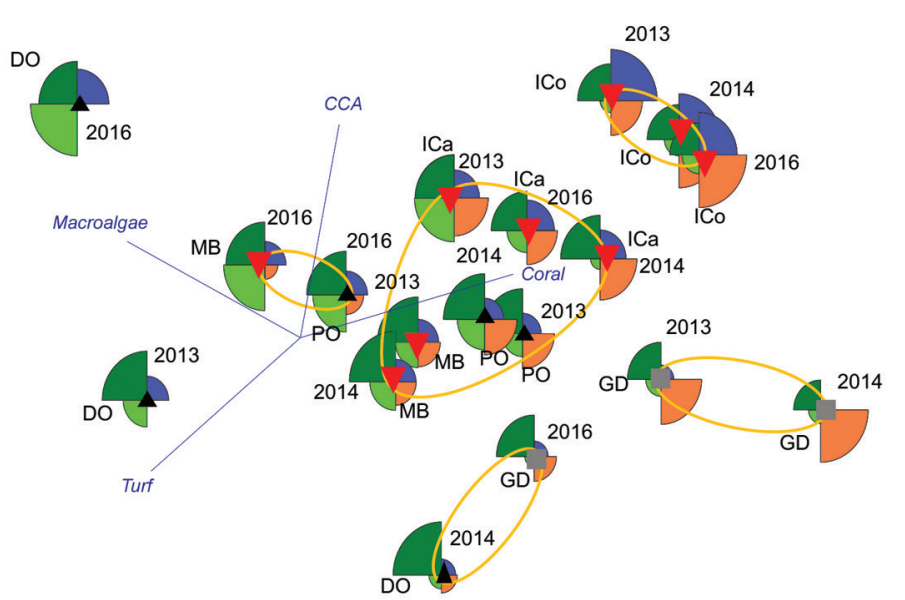

Fig. 3. Non-metric multi-dimensional scaling analysis (nMDS) based on a Bray-Curtis similarity matrix, using the average coverage values of the benthos by location and using the following factors: 1) Management category (MPA: Marine Protected Area; MRFA: Marine Responsible Fishing Area, NoMPA: Unprotected site) and 2) year of sampling; in the coral reefs of the Pacific of Costa Rica.

\section{DISCUSSION}

The present study showed that the 20152016 El Niño had a negative impact on the coral reefs and coral communities of the Pacific of Costa Rica. Across the sites, LCC decreased by an average of $50 \%$. Golfo Dulce reefs were the most affected by the phenomenon, with a $75 \%$ reduction in LCC. Other localities such as Isla del Caño and Isla del Coco experienced coral bleaching (C. Sánchez com. pers., G. Golfín com. pers.) but either did not experience a significant decrease in LCC or experienced a rapid recovery to LCC values similar to or higher than those prior to the El Niño. Our results also suggest that both MPA and MRFA conservation strategies have a positive effect on the condition of the reefs.

Our findings reveal that the Pacific reefs of Costa Rica have different levels of resilience to the impact of El Niño phenomenon. The differences observed between localities throughout the study period could be related to factors such as the years elapsed since the creation of the protected areas, the distance to human population centers and other sources of anthropic pressure, as well as the level of implementation of conservation strategies (Edgar et al., 2014).
In turn, the difference in the impact of coral bleaching is due to the particular oceanographic conditions between the locations and the time the surface waters remain warm (Fig. 1). Coco Island is influenced by more oceanic conditions where the circulation time of surface waters is faster (Lizano, 2008). On the other hand, Golfo Dulce is a semi-closed bay, with a deep basin (about $200 \mathrm{~m}$ ) and a shallow mouth (about $40 \mathrm{~m}$ ), where the circulation time is slower (Svendsen et al., 2006; MoralesRamírez, Acuña-González, Lizano, Alfaro, \& Gómez, 2015). This slower circulation means that the hot waters in the Gulf are retained for a longer period, favoring bleaching. The highest mortality in the Golfo Dulce is due to the fact that the water was hot for more than four months, causing almost $100 \%$ of the colonies to bleach during that period (J. Kleypas com. pers.). In this regard, Cocos Island can function as a refuge from temperature changes that can drastically affect corals as proposed elsewhere (Riegl \& Piller, 2003; McClannahan, Ateweberhan, Muhando, Maina, \& Mohammed, 2007; Van Woesik et al., 2012).

The oldest conservation actions were established at the end of the 1970s in Isla del Coco and Isla del Caño. Both locations have 
TABLE 2

Percentage Similarity Analysis (SIMPER) of the bottom coverage of the coral reefs of the Pacific coast of southern Costa Rica and Coco Island according to management category and year of sampling

\begin{tabular}{|c|c|c|c|}
\hline Group & Average and standard similarity & $\%$ Contribution & $\%$ Cumulative \\
\hline \multicolumn{4}{|c|}{ Management category } \\
\hline \multicolumn{4}{|c|}{ Similarity } \\
\hline \multicolumn{4}{|l|}{ NoMPA } \\
\hline Turf & $46.48 \pm 11.74$ & 55.90 & 55.90 \\
\hline $\mathrm{CCA}$ & $18.27 \pm 5.88$ & 21.98 & 77.88 \\
\hline \multicolumn{4}{|l|}{ MPA } \\
\hline Turf & $37.40 \pm 10.73$ & 42.58 & 42.58 \\
\hline Coral & $23.46 \pm 4.33$ & 26.71 & 69.29 \\
\hline \multicolumn{4}{|l|}{ MRFA } \\
\hline Turf & $41.73 \pm 22.89$ & 47.39 & 47.39 \\
\hline Coral & $32.27 \pm 5.49$ & 36.65 & 84.04 \\
\hline \multicolumn{4}{|l|}{ Dissimilarity } \\
\hline \multicolumn{4}{|l|}{ NoMPA \& MPA } \\
\hline Coral & $7.37 \pm 1.27$ & 45.48 & 45.48 \\
\hline $\mathrm{CCA}$ & $3.63 \pm 1.33$ & 22.42 & 67.90 \\
\hline \multicolumn{4}{|l|}{ NoMPA \& MRFA } \\
\hline Coral & $10.16 \pm 1.43$ & 48.46 & 48.46 \\
\hline CCA & $4.56 \pm 1.47$ & 21.75 & 70.21 \\
\hline \multicolumn{4}{|l|}{ MPA \& MRFA } \\
\hline CCA & $6.90 \pm 2.13$ & 43.45 & 43.45 \\
\hline Coral & $4.39 \pm 1.39$ & 27.67 & 71.12 \\
\hline \multicolumn{4}{|l|}{ Year } \\
\hline \multicolumn{4}{|l|}{ Similarity } \\
\hline \multicolumn{4}{|l|}{2014} \\
\hline Turf & $41.07 \pm 9.09$ & 48.73 & 48.73 \\
\hline Coral & $24.92 \pm 4.10$ & 29.57 & 78.30 \\
\hline \multicolumn{4}{|l|}{2016} \\
\hline Turf & $40.09 \pm 8.37$ & 48.64 & 48.64 \\
\hline $\mathrm{CCA}$ & $20.46 \pm 5.43$ & 24.82 & 73.47 \\
\hline \multicolumn{4}{|l|}{ Dissimilarity } \\
\hline \multicolumn{4}{|l|}{$2014 \& 2016$} \\
\hline Coral & $6.53 \pm 1.22$ & 38.04 & 38.04 \\
\hline $\mathrm{CCA}$ & $4.56 \pm 1.44$ & 26.58 & 64.61 \\
\hline
\end{tabular}

been under a management category (National Park and Biological Reserve, respectively) for 40 years, and are categorized as Type I (highly restrictive) according to the International Union for the Conservation of Nature (IUCN) (Alvarado et al. 2012). However, the level of implementation of conservation standards differs greatly between both locations. Isla del Coco National Park is considered one of the five best MPAs in the world (Edgar et al.,
2014, Strain et al., 2018), due to the adequate implementation of management actions and the high economic investment aimed at conservation. At the same time, its geographical position (located $550 \mathrm{~km}$ from the continental coast of Costa Rica) confers a high degree of isolation protecting these marine ecosystems from sources of anthropogenic pressure such as agricultural runoff, wastewater, sedimentation, and eutrophication. In addition, fishing 
in this MPA has been totally prohibited since 2001 (Alvarado et al., 2016). Finally, tourism pressure at this locality is lower than in other MPAs of the continent, with an annual average of 2700 visitors (Moreno-Díaz, 2012). In contrast, the Isla del Caño Biological Reserve is located only $24 \mathrm{~km}$ from the nearest population center (Drake Bay) and has a high tourist visitation all year round (about 30,000 people in 2017), the main activities being scuba, snorkeling (Naranjo-Arriola, 2018) and sightseeing of cetaceans (Montero-Cordero \& Lobo, 2010). Although the management actions in Isla del Caño have not been rigorously evaluated, they are likely to be low relative to the need for adequate personnel and equipment to implement them. Despite this, the geographical isolation of Caño Island does protect it to a large extent from direct impacts of normal human activities in the coastal region.

The remaining reef sites evaluated here are coastal (Table 2), they are close to sources of anthropogenic pressure, and implementation of established conservation actions are low to nonexistent (e.g. Marino Ballena and Golfo Dulce). The inadequate protection of these locations makes them more vulnerable to marine warming events since their resilience is lowered by these other stress factors (Hughes et al., 2010; Mumby \& Steneck, 2011; Richmond et al., 2018). Anthropogenic pressures such as overfishing, pollution, and coastal erosion add to the natural disturbances that impact coral reefs, and this greatly reduces their capacity for recovery. The lack of execution of management actions in Marino Ballena National Park and the Golfo Dulce Responsible Fishing Marine Area, for example, is becoming a harmful factor for coral health.

The resilience of the coral reefs of Isla del Coco is a key factor for the conservation of the coral reefs of the Pacific of Costa Rica and other regions of the Eastern Tropical Pacific (ETP). A recent study determined that this island is a possible source of larval export for other ETP reefs (Romero-Torres, Treml, Acosta, \& PazGarcía, 2018), thus the resilience of these corals amplifies the sites' importance in seeding other locations with bleaching-resistant corals. In addition to this, it is important to mention the key role of the changes in the clades of more resistant zooxanthellae (clade D) that have been able to occur in the reefs of Costa Rica, as has been determined for Panama and the Galapagos Islands (Baker, Starger, McClanahan, \& Glynn, 2004; Cunning, Glynn, \& Baker, 2013; Cunning et al., 2015). In turn, these adaptations are favored by greater reproductive success in their corals (Guzmán \& Cortés, 2001, 2007). In this context, understanding the zooxanthellae composition of Coco Island corals would be crucial for coral reefs resilience across the ETP region.

Although it is true that the intensity of 2015-2016 El Niño phenomenon was not as intense as was originally projected (Varotsos, Tzanis, \& Sarlis, 2016), its impact on continental coastal waters was enough to reduce the LCC of the reefs in Pacific coast of southern Costa Rica except for those Isla del Coco. Although MPAs are not sufficient to protect coral reefs from future bleaching events - the Great Barrier Reef, for example, which is one of the best-managed marine parks in the world, lost $50 \%$ of its corals during bleaching events in 2016 and 2017 (Hughes et al., 2018, 2019) - they do appear to be excellent tools to increase resilience to bleaching, and to enhance recovery following bleaching events. To be effective, however, MPAs need to be accompanied by efficient and effective management actions (Strain et al., 2018). They should also be complemented with other initiatives, such as effective marine spatial planning of production activities at sea, initiatives such as coral restoration that help propagate species that are more resistant to stress (Rinkevich 2005, 2014; Van Oppen, Olivera, Putnamb, \& Gates, 2015; Van Oppen et al., 2017), and citizen-based initiatives (Hesley, Burdeno, Drury, Schopmeyer, \& Lirman, 2017) and marine environmental education projects (Chabanet et al., 2018) that support all of the above. It is the synergy of these conservation actions that ensures a promising future for current coral reefs. 
Only forty years ago, we were accustomed to healthy reefs with close to $60-80 \%$ of live coral cover (Sale, 2008; Mumby, 2017). We currently live in a period of change where the average global coral coverage is less than $25 \%$, a value that in the " 80 s was considered "mediocre" but has now become the norm (Mumby, 2017). The 2015-2016 El Niño decreased LCC of the coral reefs of the Costa Rican Pacific, but at the same time, it revealed an improved resistence of some reefs to bleaching that correlated with their degree of protection. While we cannot rule out other factors, such as past bleaching events which may have winnowed out the less resilient corals, or regional differences in the severity and/or duration of the thermal stress, this analysis provides evidence of the need to reinforce all management actions, as a primary step toward maintaining a level of reef health that can be sustained into the future.

Ethical statement: authors declare that they all agree with this publication and made significant contributions; that there is no conflict of interest of any kind; and that we followed all pertinent ethical and legal procedures and requirements. All financial sources are fully and clearly stated in the acknowledgements section. A signed document has been filed in the journal archives.

\section{ACKNOWLEDGEMENTS}

The present investigation would not have been possible without the support of the following people in the field: J. Cortés, E. Ochoa, S. Mena, A. Beita, A. Ayala, J.C. Hernández, B. Alonzo, M. Espinoza, K. García, J. Sibaja, V. Bogantes, C. Salas, C. Sheridan, G. Bunnin, R. Mosquera, E. Solano, P. Miranda, F. Flores, JL Monge, J. Pericas, D. Quesada, C. Cruz. S. Conejo, J.M. Camargo, A. Arce, A. Suarez, J. Nivia, A. Quesada, N. Sandoval, J.C. Azofeifa, F. García, and J.J. Fernández. Likewise, the work was strengthened by the support of F. Monge, Sparrow Tours, Taboga, A. Vargas, D. Vargas, Cabinas Mar y Luna, Hotel La Perla de Bahia, Undersea Hunter Group, colleagues from CIMAR and ACOSA officials and ACMIC. A special thanks to Conservation International for believing in this type of research. This project was supported financially by Conservation International and CIMAR. It also had the endorsement of SINAC through resolutions 015-2013, 065-2013-SINAC, 2016-I-ACMIC-022 and INV-ACOSA-002-17 and is registered with the UCR Foundation (2739- 019, 3013-001) and in the Vice-Rector for Research of the University of Costa Rica (808-B3-503, 808-B6-520). Finally, we are grateful to J. Kleypas, for her review and comments that improved this paper.

\section{RESUMEN}

Impacto del fenómeno EI Niño 2015-2016 en arrecifes coralinos del Pacífico de Costa Rica. Introducción: El fenómeno El Niño del 2015-2016 fue considerado como uno de los más severos a nivel mundial, causando el tercer evento global de blanqueamiento coralino. Eventos previos de alta intensidad (1982-83 y 1997-98), causaron altas mortalidades coralinas y el deterioro de estructuras arrecifales a lo largo de Pacífico Tropical Oriental, afectando tanto al ecosistema como las actividades económicas asociadas. Objetivo: El objetivo de este estudio, fue determinar el impacto del evento El Niño 2015-2016 en la salud de los arrecifes coralinos de la Isla del Coco y la costa Pacífico Sur de Costa Rica. Métodos: La evaluación de los arrecifes de coral se realizó antes (2013-2014) y después (2016) de la perturbación, utilizando censos visuales subacuáticos en transectos de banda, con el fin de cuantificar la cobertura del fondo a distintas profundidades. Resultados: En general, la cobertura coralina viva promedio disminuyó 50\% después del evento El Niño 2015-2016, siendo Golfo Dulce la zona más afectada con una reducción del 75\%. Sin embargo, en ciertas localidades como las islas Coco y Caño, los efectos de El Niño fueron aparentemente mínimos, ya que no se detectó una pérdida sustancial de la cobertura coralina viva. Las diferencias en el nivel de deterioro encontradas entre los arrecifes podrían estar relacionadas con varios factores, incluyendo el tiempo transcurrido desde que se estableció el área protegida, la distancia a los centros de la población humana y la efectividad en la aplicación de estrategias de manejo. Conclusiones: El impacto sinérgico del evento E1 Niño 2015-2016 y otros factores de estrés (por ejemplo, la pesca ilegal y el desarrollo costero no regulado) incrementó los niveles de perturbación en los arrecifes coralinos, amenazando su estructura y funcionamiento. Es necesario fortalecer las estrategias de conservación para mejorar la resiliencia de los arrecifes coralinos ante el impacto de perturbaciones naturales y antropogénicas. Acciones concretas como la 
jardinería de corales, la educación ambiental marina y el ordenamiento espacial marino, deben convertirse en herramientas importantes para mantener la buena salud de los arrecifes coralinos y asegurar la sostenibilidad de los bienes y servicios proporcionados por estos ecosistemas.

Palabras claves: blanqueamiento coralino; El Niño; algas calcáreas costrosas; estrategias de conservación; áreas marinas protegidas; resiliencia.

\section{REFERENCES}

Alvarado, J. J., Cortés, J., Esquivel, M. F., \& Salas, E. (2012). Costa Rica's Marine Protected Areas: status and perspectives. Revista de Biología Tropical, 60, 129-142. doi: 10.15517/rbt.v60i1.2657

Alvarado, J. J., Herrera, B., Corrales, L., Asch, J., \& Paaby, P. (2011). Identificación de las prioridades de conservación de la biodiversidad marina y costera en Costa Rica. Revista de Biología Tropical, 59, 829-842.

Alvarado, J. J., A. Beita, S. Mena, C. Fernández-García \& A. G. Guzmán. (2015). Ecosistemas coralinos del Área de Conservación Osa, Costa Rica: análisis estructural y necesidades de conservación. Revista de Biología Tropical, 63 (Supl. 1), 219-259 doi:10.15517/rbt.v63i1.23105.

Alvarado, J. J., Beita, A., Mena, S., Fernández-García, C., Guzmán, A. G., \& Cortés, J. (2016). Ecosistemas coralinos del Parque Nacional Isla del Coco, Costa Rica: análisis estructural y temporal. Revista de Biología Tropical, 64 (Supl. 1), 153-175. doi: 0.15517/ rbt.v64i1.23423

Alvarado, J. J., Aburto-Oropeza, O., Abad, R., Barraza, E., Brandt, M., Cantera, J., Estrada, P., Gaymer-García, C., Guzmán, A. G., Herlan, J. J., \& Maté, J. (2017). Coral Reefs Conservation along the Eastern Tropical Pacific. In Glynn, P. W., Manzello, D. P., \& Enochs, I. C. (Eds). Coral Reefs of the Eastern Tropical Pacific: Persistence and Loss in a Dynamic Environment (pp. 565-591). Berlin: Springer.

Alvarado, J. J., Beita-Jiménez, A., Mena, S., FernándezGarcía, C., Cortés, J., Sánchez-Noguera, C., Jiménez, C., \& Guzmán, A. G. (2018). Cuando la conservación no puede seguir el ritmo del desarrollo: Estado de salud de los ecosistemas coralinos del Pacífico Norte de Costa Rica. Revista de Biología Tropical, 66 (Supl. 1), 280-308. doi: 10.15517/rbt.v66i1.33300

Baker, A. C., Starger, C. J., McClanahan, T. R., \& Glynn, P. W. (2004). Corals' adaptive response to climate change. Nature, 430, 741. doi: 10.1038/430741a

Bode, M., Bode, L., Choukroun, S., James, M. K., \& Mason, L. B. (2018). Resilient reefs may exist, but can larval dispersal models find them? PLoS Biology, 16, e2005964. doi.org/10.1371/journal. pbio. 20059642018
Chabanet, P., Stoica, G., Carrière, S. M., Sabinot, C., Bedrossian, C., \& Ferraris, J. (2018). Impact of the Use of a Teaching Toolbox in an Awareness Campaign on Children's Representations of Coral Reefs. Frontiers of Marine Science, 5, 340. doi: 10.3389/ fmars.2018.00340.

Claar, D. C., Szostek, L., McDevitt-Irwin, J. M., Schanze, J. J., \& Baum, J. K. (2018). Global patterns and impacts of El Niño events on coral reefs: A meta-analysis. PLoS ONE, 13(2), e0190957. doi. org/10.1371/journal.pone.0190957

Clarke, K. R., \& Golrley, R. N. (2015). PRIMER v7: User manual/tutorial (p. 300). Plymouth, UK: PRIMER-E Ltd.

Cortés, J., Murillo, M. M., Guzman, H. M., \& Acuña, J. (1984). Pérdida de zooxantelas y muerte de corales y otros organismos arrecifales en el Caribe y Pacífico de Costa Rica. Revista de Biología Tropical, 32, 227-231.

Cunning, R., Glynn, P. W., \& Baker, A. C. (2013). Flexible associations between Pocillopora corals and Symbiodinium limit utility of symbiosis ecology in defining species. Coral Reefs, 32, 795-801. doi.org/10.1007/ s00338-013-1036-y

Cunning, R., Vaughan, N., Gillette, P., Capo, T., Maté, J., \& Baker, A. C. (2015). Dynamic regulation of partner abundance mediates response of reef coral symbioses to environmental change. Ecology, 96,1411-1420. doi.org/10.1890/14-0449.1

Edgar, G. J., Stuart-Smith, R. D., Willis, T. J., Kininmonth, S., Baker, S. C., Banks, S., Barrett, N. S., Becerro, M. A., Bernard, A. T. F., Berkhout, J., Buxton, C. D., Campbell, S. J., Cooper, A. T., Davey, M., Edgar, S. C., Försterra, G., Galván, D. E., Irigoyen, A. J., Kushner, D. J., Moura, R., Parnell, P. E., Shears, N. T., Soler, G., Strain, E. M. A., \& Thomson, R. J. (2014). Global conservation outcomes depend on marine protected areas with five key features. Nature, 506, 216-220. doi.org/10.1038/nature13022

Frölicher, T.L., \& C. Laufkötte. (2018). Emerging risks from marine heat waves. Nature communications, 9 , 650. doi:10.1038/s41467-018-03163-6

Glynn, P. W., Cortés, J., Guzman, H., \& Richmond, R. H. (1988). El Niño (1982-1983) associated coral mortality in relationship to sea surface temperature deviations in the tropical eastern Pacific. Proceedings $6^{\text {th }}$ International Coral Reef Symposium, Australia, 3, 237-243.

Glynn, P. W., Mones, A. B., Podestá, G. P., Colbert, A., \& Colgan, M. W. (2017). El Niño-Southern Oscillation: Effects on Eastern Pacific Coral Reefs and Associated Biota. In Glynn, P. W., Manzello, D. P., \& Enochs, I. C. (Eds). Coral Reefs of the Eastern Tropical Pacific: Persistence and Loss in a Dynamic Environment (pp. 251-290). Berlin: Springer. 
Guzmán, H. M., \& Cortés, J. (1992). Cocos Island (Pacific of Costa Rica) coral reefs after the 1982-83 El Niño disturbance. Revista de Biología Tropical, 40, 309-324.

Guzmán, H. M., \& Cortés, J. (2001). Changes in reef community structure after fifteen years of natural disturbances in the eastern Pacific (Costa Rica). Bulletin of Marine Science, 69, 133-149.

Guzmán, H. M., \& Cortés, J. (2007). Reef recovery 20 years after the 1982-83 El Niño massive mortality. Marine Biology, 151, 401-411. doi: 10.1007/ s00227-006-0495-x

Guzmán, H. M., Cortés, J., Richmond, R. H., \& Glynn, P. W. (1987). Efectos del fenómeno de "El NiñoOscilación Sureña" 1982-83 en los arrecifes coralinos de la Isla del Caño, Costa Rica. Revista de Biología Tropical, 35, 325-332.

Hesley, D., Burdeno, D., Drury, C., Schopmeyer, S., \& Lirman, D. (2017). Citizen science benefits coral reef restoration activities. Journal for Nature Conservation, 40, 94-99. doi: 10.1016/j.jnc.2017.09.001

Hughes, T. P., Graham, N. A. J., Jackson, J. B. C., Mumby, P. J., \& Steneck, R. S. (2010). Rising to the challenge of sustaining coral reef resilience. Trends in Ecology and Evolution, 25, 633-642. doi: 10.1016/j. tree.2010.07.011

Hughes, T. P., Anderson, K. D., Connolly, S. R., Heron, S. F., Kerry, J. T., Lough, J. M., Baird, A. H., Baum, J. K., Berumen, M. L., Bridge, T. C., Claar, D. C., Eakin, M., Gilmour, J. P., Graham, N. A. J., Harrison, H., Hobbs, J. P. A., Hoey, A. S., Hoogenboom, M., Lowe, R. J., McCulloch, M. T., Pandolfi, J. M., Pratchett, M., Schoepf, V., Torda, G., \& Wilson, S. K. (2018). Spatial and temporal patterns of mass bleaching of corals in the Anthropocene. Science, 359, 80-83. doi: 10.1126/science.aan8048

Hughes, T. P., Kerry, J. T., Baird, A. H., Connolly, S. R., Chase, T. J., Dietzel, A., Hill, T., Hoey, A. S., Hoogenboom, M. O., Jacobson, M., Kerwell, A., Madin, J. S., Mieog, A., Paley, A. S., Pratchett, M. S., Torda, G., \& Woods, R.M. (2019). Global warming impairs stock-recruitment dynamins of corals. Nature, 568, 387-390 doi.org/10.1038/s41586-019-1081-y

Jiménez, C., \& Cortés, J. (2001). Effects of the 1991-1992 El Niño on scleractinian corals of the Costa Rican central Pacific coast. Revista de Biología Tropical, 49 (Suppl. 2), 239-250.

Jiménez, C. E., \& Cortés, J. (2003). Coral cover change associated to El Niño, eastern Pacific, Costa Rica, 1992-2001. P.S.Z.N.: Marine Ecology, 24, 179-192. doi: 10.1046/j.1439-0485.2003.03814.x

Jiménez, C., Cortés, J., León, A., \& Ruiz, E. (2001). Coral bleaching and mortality associated with the 1997-98 El Niño in an upwelling environment in the eastern
Pacific (Gulf of Papagayo, Costa Rica). Bulletin Marine Science, 69, 151-169.

Lizano, O. G. (2008). Dinámica de aguas alrededor de la Isla del Coco, Costa Rica. Revista de Biología Tropical, 56 (Supl. 2), 31-48.

McClannahan, T. R., Ateweberhan, M., Muhando, C. A., Maina, J., \& Mohammed, M. S. (2007). Effects of climate and seawater temperature variation on coral bleaching and mortality. Ecological Monographs, 77, 503-525. doi: 10.1890/06-1182.1

Montero-Cordero, A., \& Lobo, J. (2010). Effect of tourist vessels on the behaviour of the pantropical spotted dolphin, Stenella attenuata, in Drake Bay and Caño. Journal of Cetacean Research and Management, 11, 285-291.

Morales-Ramírez, Á, Acuña-González, J., Lizano, O., Alfaro, E., \& Gómez, E. (2015). Rasgos oceanográficos en el Golfo Dulce, Pacífico de Costa Rica: una revisión para la toma de decisiones en conservación marina. Revista de Biología Tropical, 63 (Supl. 1), 131-160. doi: 10.15517/rbt.v63i1.23100

Moreno-Díaz, M. L. (2012). Actividades socioeconómicas en el Parque Nacional Isla del Coco, Costa Rica y posibles efectos de la variabilidad climática. Revista de Biología Tropical, 60 (Suppl. 3), 113-129.

Mumby, P. J. (2017). Embracing a world of subtlety and nuance on coral reefs. Coral Reefs, 36,1003-1011. doi: $10.1007 / \mathrm{s} 00338-017-1591-8$

Mumby, P. J., \& Steneck, R. S. (2011). The Resilience of Coral Reefs and Its Implications for Reef Management. In Dubinsky, Z., \& Stambler, N. (eds.). Coral Reefs: An Ecosystem in Transition (pp. 509-519). Berlin: Springer.

Naranjo-Arriola, A. (2018). Capacidad de carga turística como herramienta de manejo sostenible de los arrecifes coralinos en la Reserva Biológica Isla del Caño. Tesis de Maestía, Universidad Nacional, Heredia.

Richmond, R.H., Tisthammer, K. H., \& Spies, N. P. (2018). The Effects of Anthropogenic Stressors on Reproduction and Recruitment of Corals and Reef Organisms. Frontiers of Marine Science, 5, 226. doi:10.3389/ fmars.2018.00226

Riegl, B., \& Piller, W. E. (2003). Possible refugia for reefs in times of environmental stress. International Journal of Earth Sciences (Geologische Rundschau), 92, 520-531. doi: 10.1007/s00531-003-0328-9

Rinkevich, B. (2005). Conservation of coral reefs through active restoration measures: recent approaches and last decade progress. Environmental Science \& Technology, 39, 4333-4342. doi: 10.1021/es0482583

Rinkevich, B. (2014). Rebuilding coral reefs: does active reef restoration lead to sustainable reefs? Current 
Opinion in Environmental Sustainability, 7, 28-36. doi: 10.1016/j.cosust.2013.11.018

Romero-Torres, M., Treml, E. A., Acosta, A., \& PazGarcía, D. A. (2018). The Eastern Tropical Pacifc coral population connectivity and the role of the Eastern Pacific Barrier. Scientific Reports, 8, 9354. doi:10.1038/s41598-018-27644-2

Sale, P. F. (2008). Management of coral reefs: Where we have gone wrong and what we can do about it. Marine Pollution Bulletin, 56, 805-809. doi: 10.1016/j. marpolbul.2008.04.009

Schiermeier, Q. (2015). Hunting the Godzilla El Niño. Nature, 526, 490-491. doi: 10.1038/526490a

Strain, E. M. A., Edgar, G. J., Ceccarelli, D., Stuart-Smith, R. D., Hosack, G. R., \& Thomson, R. J. (2018). A global assessment of the direct and indirect benefits of marine protected areas for coral reef conservation. Diversity and Distributions, 2018, 1-12. doi: 10.1111/ ddi. 12838

Svendsen, H., Rosland, R., Myking, S., Vargas, J. A., Lizano, O. G., \& Alfaro, E. J. (2006). A physicaloceanographic study of Golfo Dulce, Costa Rica. Revista de Biología Tropical, 54 (Suppl. 1), 147-170.
Van Oppen, M. J. H, Olivera, J. K., Putnamb, H. M., \& Gates, R. D. (2015). Building coral reef resilience through assisted evolution. Proceeding of the National Academy of Science, 112, 2307-2313. doi: 10.1073/pnas. 1422301112

Van Oppen, M. J. H., Gates, R. D., Blackall, L. L., Cantin, N., Chakravarti, L. J., Chan, W., Cormick, C., Crean, A., Damjanovic, K., Hepstein, H., Harrison, P., Jones, T. A., Miller, M., Pears, R. J., Peplow, L. M., Raftos, D. A., Schaffelke, B., Stewart, K., Torda, G., Wachenfeld, D., Weeks, A. R., \& Putnam, H. M. (2017). Shifting paradigms in restoration of the world's coral reefs. Global Change Biology, 23, 3437-3448. doi:10.1111/gcb.13647

Van Woesik, R., Houk, P., Isechal, A. L., Idechong, J. W., Victor, S., \& Golbuu, Y. (2012). Climate-change refugia in the sheltered bays of Palau: analogs of future reefs. Ecology and Evolution, 2, 2474-2484. doi: 10.1002/ece3.363

Varotsos, C., Tzanis, G., \& Sarlis, N. V. (2016). On the progress of the 2015-2016 El Niño event. Atmospheric Chemistry and Physics, 16, 2007-2011. doi: 10.5194/ acp-16-2007-2016

Weinberg, S. (1981). A comparison of coral reef survey methods. Bijdragen tot de Dierkunde, 51, 199-218. 